\title{
Insights on the Effects of Resveratrol and Some of Its Derivatives in Cancer and Autoimmunity: A Molecule with a Dual Activity
}

\author{
Elena Gianchecchi ${ }^{1,2}$ and Alessandra Fierabracci ${ }^{2, *(D)}$ \\ 1 VisMederi srl, Strada del Petriccio e Belriguardo, 35, 53100 Siena, Italy; elegianche@yahoo.it \\ 2 Infectivology and Clinical Trials Research Department, Children's Hospital Bambino Gesù, \\ Viale San Paolo 15, 00146 Rome, Italy \\ * Correspondence: alessandra.fierabracci@opbg.net
}

Received: 8 January 2020; Accepted: 20 January 2020; Published: 22 January 2020

check for updates

\begin{abstract}
In recent years, the interest in natural compounds exerting immunoregulatory effects has enormously increased. Among these, the polyphenol resveratrol, found in a variety of foods and beverages, including red grapes and red wine, has been demonstrated to exert both in vitro and in vivo biological activities. More specifically, it has antiaging, cardioprotective, antioxidant, immunomodulatory, anti-inflammatory and chemopreventive activities. Due to its anti-proliferative, pro-apoptotic and immunoregulatory effects, resveratrol has gained substantial attention for the treatment of cancer or autoimmunity, which represent frequently diagnosed diseases with important consequences for the health of the patients affected. The aim of the present review is to focus on the role of resveratrol in the modulation of cancer as well as of several organ-specific or systemic autoimmune diseases, including autoimmune hepatitis, type 1 diabetes mellitus, inflammatory bowel disease, rheumatoid arthritis, systemic lupus erythematosus and multiple sclerosis.
\end{abstract}

Keywords: resveratrol; cancer; autoimmunity

\section{Introduction}

Traditional medicine, often recognized as complementary, alternative, or nonconventional medicine [1,2], relies on the use of bioactive natural compounds [3]. Many of these compounds are well known in scientific literature since they are traditionally used by various cultures worldwide $[3,4]$.

In this regard, several classes of agents exerting anti-mutagen and anti-carcinogen activities have been identified in foods and beverages of natural origin [5]. A wide variety of polyphenolic compounds, described especially in vegetables and fruits (in particular in grapes and their derivatives), have attracted attention for their beneficial health properties as promising antitumor agents [6].

Resveratrol (trans 3,5, $4^{\prime}$-trihydroxystilbene) is a natural non-flavonoid polyphenol found in its trans isomer form produced by many different plant species, such as red grapes varieties [7], peanuts [8], blueberries [9], and rhubarb [10]. This compound plays several biological activities having anticancer [11,12], antimicrobial [13,14], antioxidative [15], anti-neurodegenerative [16], anti-inflammatory and immunomodulatory properties in vitro and in vivo $[17,18]$ and estrogenic effects in vitro [19]. Indeed, this polyphenol exerts a role towards adverse conditions including environmental stress, injury, or pathogenic attack, i.e., UV irradiation and fungal infection [20].

Firstly identified by Takaoka from white hellebore (Veratrum grandiflorum) in 1939, resveratrol was afterwards considered as a phytoalexin [21]. Remarkably, in 1992, Siemann [22] discovered its presence in red wine. This result was later used to explain the so-called "French Paradox", referring to the low rates of coronary heart disease mortality in some areas of France, despite the elevated intake of 
fat and cholesterol through the daily diet of residents [23]. In 1997, Jang and coworkers discovered that resveratrol could prevent cancer development [24]. Several benefits from resveratrol are attributed to its antioxidant properties although its cardioprotective, immunomodulatory, anti-inflammatory and chemopreventive activities rely on other mechanisms [24].

Regarding the antioxidant potential of resveratrol, this compound is both a free radical scavenger as well a strong antioxidant due to its ability to induce the activities of numerous antioxidant enzymes [25]. In particular, the antioxidant capacity of polyphenolics is attributed to the redox properties of their phenolic hydroxyl groups and the potential for electron delocalization across the chemical structure [26]. Over the last ten years, several studies have highlighted the critical role played by reactive oxygen species (ROS) in arbitrating the development of oxidative stress [27]. Whereas reduced levels of ROS synthesis allow the maintenance of physiological functions, such as proliferation, signal transduction, gene expression and host defense [27], an excess in ROS accumulation could be harmful due to the oxidative changes affecting cellular macromolecules (lipid, proteins and nucleic acids) characterized by detrimental potential.

Indeed, deoxyribonucleic acid (DNA) injury by ROS, which can cause potential single- and double-stranded DNA breaks by reacting with the nitrogenous bases and the sugar phosphate backbone, has been correlated with mutagenesis, oncogenesis and aging [28]. Among the oxidative lesions in DNA there are not only strand breaks but also base modifications, sugar damage, and abasic sites [29]. Due to the ability of oxidants, antioxidants and other determinants of the intracellular redox state to modulate gene transcription, ROS changes within mammalian cells can also modify the expression of numerous mammalian genes, such as oncogenes and amyotrophic lateral sclerosis-linked genes during transcription, as recently demonstrated by Li [30].

In the last years, there has been quick progress in clarifying the molecular mechanisms responsible for the antitumor effects of resveratrol [31]. More specifically, the chemopreventive ability of resveratrol has been linked to its ability to halt the activation of different carcinogens and/or to promote their detoxification, to avoid oxidative damage of target cell DNA, to lower inflammation and to reduce the proliferation of tumor cells [31,32]. The chemotherapeutic potential of resveratrol both in vitro and in vivo is sustained by the inhibition of angiogenic and metastatic processes of cancer progression and attenuation of chemotherapy resistance [33]. Resveratrol promotes the apoptosis of various premalignant or cancerous cells by regulating or inhibiting multiple pathways including the PI3K/Akt/mTOR and the mitogen-activated protein kinase pathways (MAPK) [34]. These abilities can underlie its chemopreventive and chemotherapeutic potential.

Approximately 18 years ago, resveratrol was proposed as an immune modulator able to regulate both innate and adaptive immune responses through interaction with several molecular pathways [35]. Indeed, experimental evidence in cell lines and animal models has demonstrated the immunomodulatory activity of resveratrol with dose-dependent opposite effects. More specifically, the compound acts as an immunosuppressive when administered at high doses, whilst at low doses it stimulates the immune system [36].

The effect of the molecule has been observed on several immunotypes producing macrophage, $\mathrm{T}$ cell and natural killer (NK) cell activation as well as being involved in the suppressive function of $\mathrm{CD} 4+\mathrm{CD} 25+$ regulatory cell subsets $[35,37]$. The molecule has also effects on $\mathrm{B}$ cell proliferation and autoantibodies production $[17,38]$.

As reported by several in vivo studies conducted in animals and humans, resveratrol is characterized by a low oral bioavailability [39] due to a very limited intestinal uptake of the molecule [40]. This leads to minimum amounts in the bloodstream because of the extensive metabolism occurring in the gut [41] and liver [42]. The short initial half-life of the primary molecule is essentially caused by its rapid metabolism. The bulk of an intravenous dose of resveratrol is processed in sulfate conjugates in just 30 minutes in humans [43]. Several other natural stilbenoids, as well as those derived by the synthetic modification of the stilbene scaffold [44-46], present a similar structure to resveratrol, linked 
to its potential metabolism. They could have some of the beneficial properties of the parent molecule and produce even larger benefits [47].

Studies of these derivatives have constituted the basis for the development of novel resveratrol analogues through specific changes of the stilbene scaffold-achieving molecules with a stronger antitumor effect or other properties. The substitution of the hydroxyl groups with methoxyl groups meaningfully enhances resveratrol bioavailability by boosting its intestinal absorption and increasing hepatic stability [47]. For this reason, different methoxylated analogues of resveratrol have been formulated with the purpose of obtaining novel agents for cancer chemoprevention.

Along with resveratrol, several other stilbenes, with a similar structure to resveratrol, are naturally present in food. For example, pterostilbene (trans-3,5-dimethoxy-4'-hydroxystilbene), which is a structural analog of resveratrol generated by the substitution of two hydroxyl groups with two methoxyl groups, has been found in blueberries and has been studied most widely [48]. A higher lipophilicity of pterostilbene over resveratrol has been obtained through the substitution of hydroxyl with methoxyl groups resulting in better bioavailability. These differences in pharmacokinetics might account for the higher biological activity of pterostilbene over the parental compound resveratrol [48]. Pterostilbene, as resveratrol, is also not toxic when used at high dosages in humans [49].

Pterostilbene has been reported to exert various pharmacologic effects, including anticancer, anti-proliferative, pro-apoptotic, antioxidant, anti-inflammatory, anti-invasive and antimetastatic activities [48]. Pterostilbene has also been demonstrated to act specifically against tumor cells without triggering any acute toxicity to normal cells (reviewed in [50]).

In this review, we summarized the most recent updates on the effects of resveratrol in the management of cancer and chronic inflammatory conditions, such as autoimmune diseases (Figure 1).

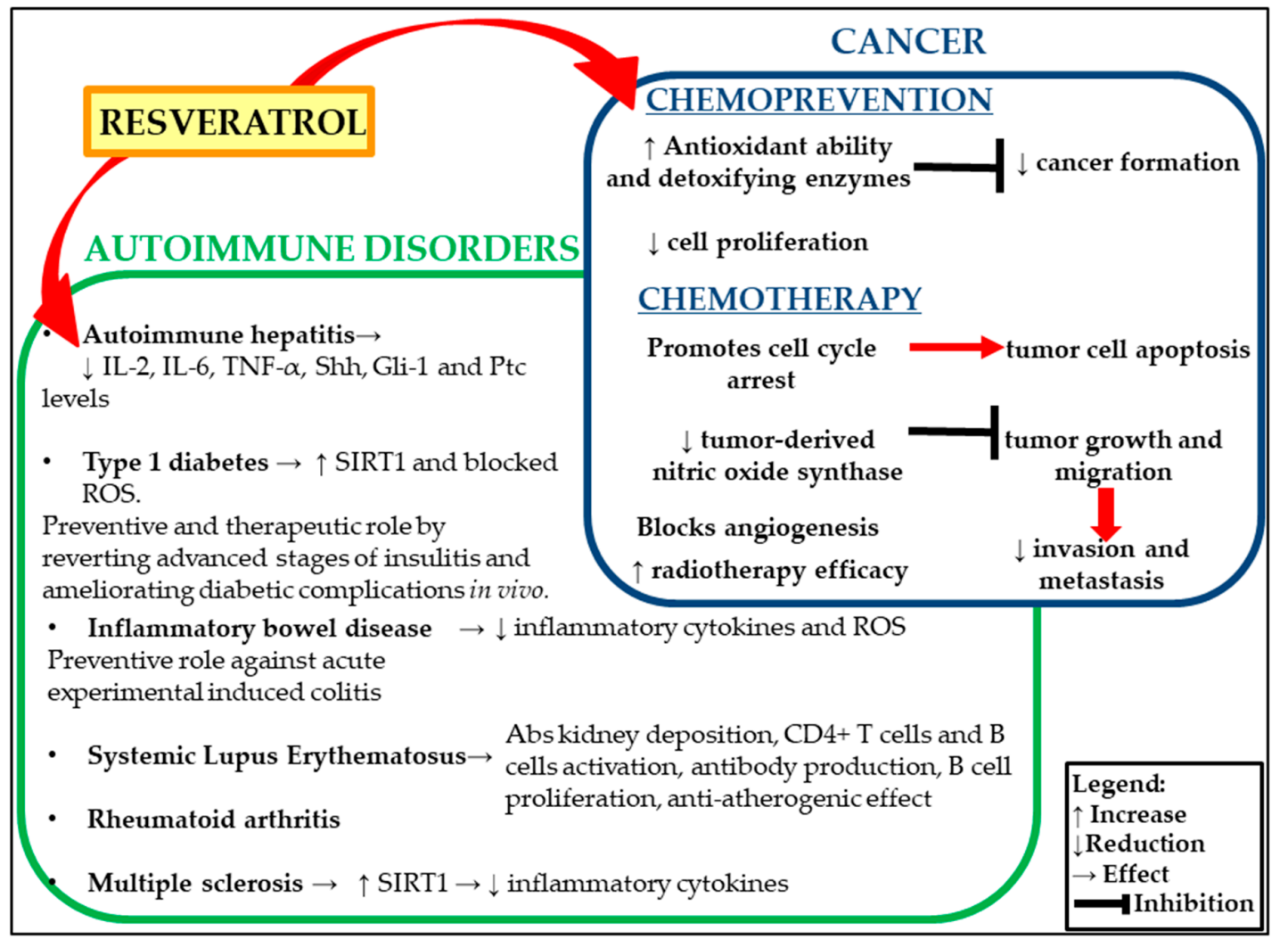

Figure 1. Dual role of resveratrol on autoimmune disorders and cancer. 


\section{Resveratrol and Cancer}

During the development of cancer, there is a complex orchestrated progression wherein, due to genetic mutations, normal cells do not stop to grow, invade normal tissues and metastasize. Despite considerable efforts to find a treatment, this pathologic condition constitutes one of the most frequently diagnosed diseases whose morbidity and mortality represents a significant health issue globally. More specifically, it is the second cause of death in the world, having caused 9.6 million deaths in 2018 [51].

The ability of the compound to influence one step of this process attracts considerable attention since it could putatively represent an anticancer drug, which could be used in clinical settings [34].

For decades, the attention towards resveratrol has increased for its role in preventing and treating numerous pathologies, such as tumor, neurodegenerative, cardiovascular, inflammatory, and even autoimmune diseases. A growing amount of research has demonstrated that resveratrol induces cytotoxicity towards cancer both in vitro and in vivo and plays a chemopreventive role.

The properties of resveratrol so far identified can be summarized as the following: resveratrol is able to induce the block of cell cycle causing the apoptosis of cancer cells, through the downregulation of tumor-derived nitric oxide synthase; furthermore, it halts the growth of cancer cells and their migration; its antioxidant ability avoids DNA damage responsible for tumor formation; and it regulates nuclear factor NF- $\mathrm{BB}$ activation [52].

Resveratrol has antitumor activity in different human cancers such as hepatocellular carcinoma [53] and ovarian carcinoma [54]. Recently, Zhong and colleagues [55] investigated the anti-tumoral effect of resveratrol in vivo in a rat orthotopic ovarian cancer (OC) model reporting that its intraperitoneal administration halted cancer cell proliferation without affecting normal tissues. In greater detail, the blockade of glycolysis and inhibition of AMPK/mTOR signaling induced by resveratrol were responsible for its antitumor activity in ovarian cancer cells [56]. Recently, Zhang and colleagues [57] reported for the first time that resveratrol promoted not only apoptosis but also immunogenic cell death of human and murine ovarian carcinoma cells.

In addition, resveratrol has been extensively investigated for its ability to enhance cell killing by radiation [58] and ionizing radiation (IR) mediated apoptosis in cancer cells [59].

On a general ground, the cellular effects of polyphenols, such as anti-proliferative and pro-apoptotic actions, have been recently correlated with their ability to modify the activity of topoisomerases [60]. These ubiquitous nuclear enzymes regulate the topological state of DNA by breaking and resealing one or both strands of a DNA duplex. Whereas lower eukaryotes, such as yeast and Drosophila, possess a single type II topoisomerase, eukaryotic cells have type II topoisomerase (Topo II) isoforms $\alpha$ and $\beta$. These two isoforms act in the principal cellular processes, engaging DNA by generating intermediate cleavable or covalent complexes with a short half-life [61]. Topo II plays a fundamental role in the survival of all eukaryotic cells constituting both an enzyme and a structural component of the nuclear matrix. It modulates the topological states of DNA by transient cleavage, strand passing and re-ligation of double-stranded DNA resulting in catenation, decatenation, knotting or unknotting of DNA molecules and relaxation of supercoiled DNA [62]. In addition, Topo II has a critical function in DNA replication and is necessary for condensation and segregation of chromosomes. Topo II expression depends on the cell cycle and its protein levels and catalytic activity reach a peak at G2/M. Topo II phosphorylation/dephosphorylation was supposed to constitute one of the regulatory checkpoints at the entry and progression of mitosis [61]. Topo II represents the molecular target of resveratrol, as supported by a growing number of studies $[63,64]$ and elucidated recently by Lee and colleagues [60]. Recently, resveratrol was found to antagonize the expression of checkpoint genes and proliferative genes induced by thyroxine in human oral cancer cells [65].

Furthermore, resveratrol coadministration with other chemotherapeutic drugs was deeply helpful for cancer therapy in vitro and in vivo. Resveratrol and 5-fluorouracil coencapsulation in liposomal nanocarriers showed a higher cytotoxicity compared to the free drug combination when tested in vitro on head and neck cancer cell lines [66]. Doxorubicin (DOX) and resveratrol co-treatment overcame drug resistance by promoting the deregulation of the cell cycle and apoptosis in a B16/DOX murine melanoma 
model, lengthening mice survival compared to the untreated counterparts [67]. In a glioma nude mouse model, the combination of resveratrol with temozolomide (TMZ) potentiated the therapeutic efficacy of the latter both in vitro and in vivo [68]. More specifically, the combined treatment promoted apoptosis as well as cell differentiation and blocked the metastatic process by consistently inhibiting cell migration. Yuan [68] observed in fact that the therapy was able to induce glial fibrillary acidic protein (GFAP) expression, a marker characterizing differentiated astrocytes lost frequently with increasing grade of malignancy. Furthermore, the expression of matrix metalloproteinase-9 (MMP-9), which is an extracellular protease having a role in cell migration across basement membranes, was reduced. The recent study conducted by Zeng [69] demonstrated that resveratrol tumor necrosis factor-related apoptosis-inducing ligand (TRAIL) combination treatment was able to sensitize renal cell carcinoma (RCC) cells to TRAIL-induced death in vitro. When the co-treatment was administered in nude mice, the RCC xenograft growth was considerably reduced. In adriamycin-resistant leukemia K562/RA cells, when resveratrol was co-administered with arsenic trioxide (ATO), the apoptotic effect of the latter was potentiated. In addition, resveratrol diminished the toxicity of ATO alone.

In breast cancer cells, pterostilbene induces apoptosis in a caspase-dependent manner. More specifically, effector caspase-3 and -7 activation could be due to the loss of mitochondrial membrane potential and to the generation of superoxide anions. In the same way, caspase-dependent apoptosis upon treatment with pterostilbene is correlated with ROS generation, loss of mitochondrial membrane potential, cytochrome c release, a shift in the balance of pro- and anti-apoptotic B-cell lymphoma-2 (Bcl-2) proteins, and activation of caspases in a human gastric carcinoma cell line [70]. Furthermore, pterostilbene inhibits cell proliferation and cell cycle progression in a concentration- and time-dependent manner. For this purpose, cell cycle progression is blocked by pterostilbene at the G1 phase, associated by an increase in p53, p21, p27 and p16 proteins and a concomitant reduction in cyclin A, cyclin E and cyclin-dependent kinase (Cdk)2, Cdk4 and Cdk6 [70].

The coadministration of resveratrol and pterostilbene was able to synergistically inhibit the growth of triple-negative breast cancers (TNBC), representing about $10 \%-20 \%$ of total breast cancer. This was associated with a reduction in silent information regulator 1 (Sirtuin 1, SIRT) expression, a type III histone deacetylase (HDAC) involved in many molecular events, such as cancer and immune tolerance including the maintenance of peripheral $\mathrm{T}$ cell tolerance, and DNA methyltransferases (DNMTs) enzymes [71]. A subsequent study conducted by the same group [72] revealed that resveratrol/pterostilbene co-treatment was able to restore Estrogen Receptor- $\alpha$ (ER $\alpha)$ expression in ER $\alpha$-negative breast cancer cells, characterized by a higher aggressivity and no response to conventional hormone-directed therapies. The study confirmed the role played by nutritional factors as regulators of gene expression. Furthermore, the use of these plant-based dietary compounds in combinatorial treatment allows one to overcome the side effects caused by conventional therapies used to reestablish ER $\alpha$ expression. The encapsulation of resveratrol into oxidized mesoporous carbon nanoparticles (oMCNs) could increase the solubility of resveratrol and improve the in vitro release property, leading to greater cytotoxic and pro-apoptotic effects [73]. The recent study conducted by Thipe [74] demonstrated that the use of resveratrol-conjugated gold nanoparticles improved resveratrol bioavailability and was effective against breast (MDAMB-231), pancreatic (PANC-1) and prostate (PC-3) tumor cell lines.

In several studies, the 3,4,5,4'-trans-tetramethoxystilbene (TMS) was reported as the most potent pro-apoptotic analog of resveratrol (reviewed in [75]).

TMS was also able to promote both apoptosis and autophagy in gefitinib-resistant (G-R) non-small-cell lung carcinoma (NSCLC) cells, whereas any inhibitory activity was exerted on other NSCLC cells and normal lung epithelial cells [76]. The mechanisms in resveratrol and its derivatives played their effects on NSCLC were elucidated by Lu and colleagues, who demonstrated that trans-3,5,4'-trimethoxystilbene diminished gefitinib resistance in NSCLCs [77], revealing that it occurred through the inhibition of the MAPK/Akt/Bcl-2 pathway by upregulating miR-345 and 498. A study conducted by Stivala et al. [78] described the stronger antioxidant effect of resveratrol compared to 3,5,4'-trimethoxystilbene. In addition, 3,5,4'-trimethoxystilbene was proven considerably 
more potent in inhibiting angiogenesis than resveratrol. When 3,5,4'-trimethoxystilbene was used, intersegmental vessel regression and downregulation of vascular endothelial growth factor receptor 2 (VEGFR2) mRNA expression were observed in zebrafish; in addition, 3,5,4'-trimethoxystilbene caused G2/M cell-cycle blockade in endothelial cells of zebrafish embryos. In the regulation of neovascularization in neoplasia two principal mechanisms were identified: first, anti-angiogenic compounds block neovascularization, and second, vascular-targeting agents disrupt immature vessels [79]. It has been hypothesized that 3,5,4'-trimethoxystilbene could act as an anti-angiogenic and anti-vascular compound by reducing VEGFR2 expression and inducing cell-cycle arrest at G2/M phase [79]. In regards to the antiangiogenic and vascular-targeting activity, Belleri et al. [80] reported that 3,5,4'-trimethoxystilbene has up to 100 times higher potency compared to the parent compound resveratrol; this was assessed through endothelial cell proliferation, sprouting, collagen gel invasion and morphogenesis. The vascular-targeting of 3,5,4'-trimethoxystilbene was due to the destabilization of microtubules, representing a target of numerous cancer chemotherapeutic agents, and depolymerization of tubulin. In addition, 3,5,4'-trimethoxystilbene was able to interfere with the microtubule organization center and with the migration of the endothelial cell [80]. Moreover, 3,5,4'-trimethoxystilbene inhibited human lung adenocarcinoma cell invasion by suppressing phosphorylation of stress-activated kinases (SAPK)/c-Jun N-terminal kinase (JNK) and p38 MAPK signaling pathways. This effect was associated with a reduction in nuclear factor-kappa B (NF-kB) and activator protein-1 (AP-1) proteins at nuclear level, representing two transcription factors implicated in invasion promotion. NF-kB and AP-1, in turn, induced the downregulation of matrix metalloproteinase (MMP)-2 expression [80]. Both 3,5,4'-trimethoxystilbene and resveratrol halted the migratory and invasive properties of HepG2 and Hep3B hepatocellular carcinoma cells following exposure to phorbol 12-myristate 13-acetate (PMA) and of PMA-untreated Hep3B cells. This anti-invasive effect was associated with a reduction in MMP-9 and MMP-2 activity, while tissue inhibitors of metalloproteinase (TIMP)-1 and TIMP-2 protein expressions increased [81].

Another limit of resveratrol is its bioavailability, characterized also by an elevated range of interindividual variation in a sex-independent manner [48]. The intake of low doses of resveratrol generates a maximum peak plasma concentration in the first $30 \mathrm{~min}$, whereas at high doses the maximum peak plasma concentration is reached in 1.5-2h. Studies conducted in rodents demonstrated that resveratrol was eliminated rapidly at all tested doses of 5,10 , and $25 \mathrm{mg} / \mathrm{kg}$ and the half-life time was only about $2 \mathrm{~h}$ [82]. Such characteristics of resveratrol metabolism suggest that the proper way for obtaining optimal anti-tumoral effects could be a continuous drip or multiple oral administrations.

Compared to resveratrol, 3,4,5,4'-tetramethoxystilbene (DMU-212) exhibited increased pharmacological and pharmacokinetic properties with a higher metabolic stability and bioavailability [83]. In addition, DMU-212 presented a stronger inhibitory activity on the proliferation of melanoma cancer cells [84].

The putative anticancer effects of resveratrol have been also investigated in different leukemia cell lines. Indeed leukemia represents a heterogeneous group of diseases, encompassing acute myeloid leukemia, acute lymphoblastic leukemia, chronic myeloid leukemia and chronic lymphoblastic leukemia, which can be further classified into different subtypes.

Bernhard et al. [85] demonstrated that resveratrol at $20 \mu \mathrm{M}$ and higher doses arrests, in a concentration-dependent manner, the cell cycle in S-phase and apoptosis of T cell-derived T-ALL lymphocytic leukemia cell line CEM-C7H2. In addition, whereas the blocking of Fas or Fas Ligand (FasL) as well as the constitutive expression of cytokine response modifier A (CrmA) (an effective inhibitor of the Caspase family other than Caspase-6) did not impact resveratrol-induced apoptosis in CEM-C7H2, the treatment with z-IETD-fmk, an inhibitor of Caspase-6, almost totally halted the pro-apoptotic effect of resveratrol [85]. Additionally, resveratrol considerably and irreversibly blocked the growth of human chronic myeloid (K562) and acute lymphoblastic (HSB-2) leukemia cells; moreover, this effect correlated with a marked apoptosis. The sensitivity to resveratrol-induced apoptosis of the two cell lines investigated was associated with both Bax-increased expression and the release of 
cytochrome c [86]. Moreover, resveratrol inhibited growth and promoted both apoptosis and cell cycle arrest at G1 phase in a mouse lymphocytic leukemia L1210 cell line. A dose-related regulatory activity on both innate and specific immune functions to L1210 bearing mice, the increase of lymphocyte proliferation and NK activity, the normalization of CD4/CD8 ratios, a reduction in Interleukin-6 (IL-6) release and content have been observed. In particular, this last finding has been hypothesized to represent, at least in part, the mechanism of the antitumor immune activity of resveratrol [68]. In fact, this intracellular cytokine has been implicated in tumorigenesis constituting a paracrine growth factor in several cancers [87].

Similar effects have been observed in vitro also in human leukemia cell types, although the compound's mechanism of action remains yet to be clarified. Resveratrol-induced cell death of human promyelocytic leukemia (HL-60) cells was due to the proteolytic cleavage of caspase substrate poly (ADP-ribose) polymerase (PARP) and depended on CD95-signaling [88]. HL60 leukemia cells were induced to apoptosis by resveratrol in a dose-dependent manner at concentrations ranging from 8 to $32 \mu \mathrm{M}$, via promoting CD95-CD95L interaction on the cell surface [88], creating a death-inducing signaling complex (DISC) at the cytoplasmic CD95 receptor, inducing the release of cytochrome C from mitochondria, and activating Caspase- 9 and downstream Caspase- 3 in a mitochondrial-independent manner [89]. In addition, resveratrol was demonstrated not only to diminish cell viability as well as DNA synthesis, but the analysis of the cell cycle revealed that resveratrol enhanced the proportion of the subdiploid cell population in HL60 cells. Furthermore, resveratrol decreased the expression of Bcl-2, representing an anti-apoptotic protein whose role is the maintenance of mitochondrial membrane integrity [90]. This effect correlated with increased expression of the pro-apoptotic Bax protein [91], annexin A1, growth arrest-induced and DNA damage-induced gene $45 \alpha$ (GADD45 $\alpha$ ), and cleaved Caspase-3 [92]. Resveratrol used at a $100 \mu \mathrm{M}$ dose leads to growth inhibition and proliferation arrest of HL60 cells by downregulating anti-apoptotic protein Bcl-2 expression and lowering the viability of DNA synthesis [92]. Besides, resveratrol induced FasL-related apoptosis of HL-60 cells through Cdc42 activation of apoptosis signal-regulating kinase 1 (ASK1)/c-Jun N-terminal kinase (JNK) dependent signaling pathway [93]. Further investigations regarding the mechanisms underlying the pro-apoptotic effect of the compound on HL60 cells reported de novo production and accumulation of ceramide by raising the expression of ceramide-generating protein longevity assurance, and decreasing that of anti-apoptotic sphingosine kinase-1 (SK-1) and glucosylceramide synthase [94]. These results regarding the pro-apoptotic role played by resveratrol are in agreement with previous data obtained from acute myeloid leukemia (AML) cells reporting the subsequent induction of DNA repair enzyme PARP (poly adenosine diphosphate (ADP)-ribose polymerase) cleavage due to cysteine protease Caspase-3 activation occurring upon treatment with the compound [95].

In addition to proliferation blockage and cell apoptosis promotion, resveratrol was able to induce differentiation of the human erythro-megakaryoblastic leukemia cell line K562 as demonstrated by Yan et al. [96]. In more details, they reported that resveratrol induced cell differentiation by favoring glycophorin A, HBA1, HBB and $\gamma$-globin expression, in particular when used at the concentration of $50 \mu \mathrm{M}$. Conversely, the expression of these four genes was lessened when resveratrol was administered at $100 \mu \mathrm{M}$. Although in many types of cancer resveratrol supplementation has shown positive results, in others effects have been ambiguous, as reported on androgen-responsive LNCaP human prostate cancer cells in vitro and in vivo [97], and sometimes there are even detrimental effects [98,99]. This is due to resveratrol's mechanism of action, which depends on the intrinsic molecular properties of the cancer model under investigation.

Even though resveratrol has shown a promising antitumor effect in different types of cancer, reverting also the multidrug resistance in tumor cells, and increasing the therapeutic outcomes of the standard chemotherapeutic agents, additional clinical studies are necessary before its application in clinical treatment. So far the majority of the clinical trials have had the aim of investigating the safety, bioavailability, pharmacokinetics and tolerability of resveratrol, whereas its potential anticancer properties have been evaluated only in a limited number of studies. In addition, no clinical trial based 
on the co-administration of resveratrol with other antitumor drugs has been performed or is currently in progress.

\section{Resveratrol and Autoimmune Diseases}

A direct consequence of the lengthening of human life expectancy is the aging of most of the population worldwide. Aging represents a risk factor for the onset of chronic diseases, including autoimmune disorders [100]. An elevated amount of evidence has reported that age-associated disturbances involving innate immunity (immune response of neutrophils and macrophages) and adaptive immunity (B cell and $\mathrm{T}$ cell development) have a higher prevalence in respect to young subjects [100], even though the onset of the latter can occur at different ages depending on the autoimmune condition. Besides conventional treatments such as analgesics, non-steroidal anti-inflammatory drugs and glucocorticoids, innovative therapies based on therapeutic immunosuppression and biological agents, as well as molecules derived from natural products, have been widely studied for their pharmacological effect on both organ-specific and systemic autoimmune disorders [101].

\subsection{Autoimmune Hepatitis}

Autoimmune hepatitis (AIH) represents an idiopathic inflammatory pathology affecting the liver which presents a loss of self-tolerance to hepatocyte-specific autoantigen, leading to the synthesis of autoantibodies and the production of dense lymphoplasmacytic inflammatory infiltrates in the portal tracts [102]. Activation and clone expansion of T cells lead to B cell release of autoantibodies, pro-inflammatory cytokines and hepatocyte destruction finally responsible for liver failure [103]. Zhou et al. observed the protective role played by resveratrol against concanavalin-A- (ConA-) induced liver injury in mice by significantly inhibiting IL-2, IL-6, tumor necrosis factor $\alpha$ (TNF- $\alpha$ ), Sonic hedgehog (Shh), Glioblastoma- (Gli-) 1, and Patched (Ptc) levels, probably through the modulation of the hedgehog signal pathway [104].

\subsection{Type 1 Diabetes Mellitus}

Bertelli and colleagues [105] suggested the putative therapeutic application of resveratrol in type 1 diabetes mellitus (T1D) induced cerebrovascular dysfunctions upon the observation that rats affected by T1D had their vascular functions restored following long-term resveratrol treatment [105]. Yun and colleagues [106] explored the resveratrol mechanism of action by using human monocytes obtained from T1D patients, revealing that it induced the overexpression of SIRT1 and blocked the cellular oxidative stress. Resveratrol was demonstrated to have both preventive and therapeutic effects by reverting the advanced stages of insulitis affecting the islets of Langerhans in a non-obese diabetic (NOD) mice model [107]. This was due to a reduced expression of chemokine receptor 6 (CCR6) in T helper (Th17) cells and pathogenic CD11b+F4/80hi macrophages responsible for halting cell migration from peripheral lymphoid organs to the pancreas. A following study by Kaur [108] reported the amelioration of diabetic complications, as well as the loss of $\beta$-cells, pancreatic and hepatic oxidative stress in streptozotocin-induced diabetic rats treated with $25 \mathrm{mg} / \mathrm{kg}$ of resveratrol. When co-administered with insulin, resveratrol was able to improve glycemic control in diabetic rats, lowering the blood glucose to the levels reported in non-diabetic rats and cutting down glycosuria [109].

\subsection{Inflammatory Bowel Disease (IBD)}

A multifactorial origin has been hypothesized for inflammatory bowel disease (IBD) onset, encompassing Crohn's disease (CD) and ulcerative colitis (UC). Among the factors implicated in its pathogenesis, genetics, bacteria, and an altered immune system response have been identified to play a promoting role for this autoimmune disorder [110]. More specifically, the impairment in the intestinal mucosal barrier allows the translocation of commensal bacteria as well as bacterial products into the intestinal wall, activating neutrophils and macrophages located in the epithelium. As a consequence 
of such activation, inflammatory mediators, including ROS and TNF- $\alpha$, are released. The latter is synthetized especially by $\mathrm{T}$ lymphocytes upon antigen recognition.

Resveratrol could diminish inflammatory cytokines and ROS in IBD animal models [111-115]. Furthermore, resveratrol pro-drugs, which have been developed to overcome the reduced bioavailability of resveratrol due to its rapid metabolic modification, lowered colon inflammation in a murine model [111]. This allowed the preservation of mucosal structure, promoted the presence of bifidobacteria and lactobacilli implicated in the maintenance of intestinal homeostasis and was correlated with an improvement in intestinal health [116]. Resveratrol also played a preventive role against the development of acute experimental-induced colitis when this compound was administered 48, 24 and $1 \mathrm{~h}$ before trinitrobenzene sulfonic acid (TNBS) intracolonic instillation [117].

Regarding the use of resveratrol in human clinical trials, to our knowledge, only the study conducted by Samsamikor et al. [118] investigated its effect in UC patients observing a diminishment of NF-kB activity in peripheral blood mononuclear cells (PBMCs), and of TNF- $\alpha$ and high sensitivity C-reactive protein (hs-CRP) in plasma.

\subsection{Rheumatoid Arthritis}

In an adjuvant-induced arthritis rat model, when used in association with curcumin through lipid-core nanocapsules, resveratrol showed a stronger effect in reducing paw oedema compared to resveratrol alone [119]. This promising result was subsequently confirmed by Riveiro-Naveira et al. [120] in an acute antigen-induced arthritis model wherein resveratrol was administered through the diet [120]. Promising results were also observed when the molecule was tested in gouty arthritis animal models. More specifically, sodium alginate and resveratrol co-treatment lowered IL-1 $\beta$, CC-chemokine receptor 5 (CCR5) and CXC-chemokine ligand 10 (CXCL10) levels in the synovial tissue of a monosodium urate-induced mouse model of acute gouty arthritis. Further, at 6 hours after treatment, a marked improvement was observed in mice co-treated with sodium alginate and resveratrol compared to those receiving resveratrol alone [121]. A following study conducted by Chen et al. [122] reported a reduction in serum uric acid levels after resveratrol consumption by hyperuricaemic mice, allowing the hypothesis for its preventive use against recurrent attacks of gout [122].

\subsection{Systemic Lupus Erythematosus}

Resveratrol showed protective activity in a pristane-induced lupus mouse model. More specifically, it reduced proteinuria, IgM and IgG kidney deposition, and kidney histological lesions. In addition, the activation of $\mathrm{CD} 4+\mathrm{T}$ cells and $\mathrm{B}$ cells was inhibited in vitro, and antibody generation and $\mathrm{B}$ cell proliferation halted [123]. Feng et al. [124] reported the vascular protective effect of resveratrol in the ApoE-/- Fas-/-C57BL/6 mice resembling SLE. This compound had anti-atherogenic properties inducing the increase of the cholesterol efflux pathway [125]. These data were also confirmed by Voloshyna et al. [126] reporting that resveratrol countered SLE-associated atherogenicity through the normalization of cholesterol efflux.

\subsection{Multiple Sclerosis}

Miyazaki et al. [127] proved that the induction of SIRT1 with resveratrol was able to normalize the altered synthesis of pro-inflammatory cytokines by multiple sclerosis (MS) B cells through the regulation of micro RNA (miR)-132 expression. In more detail, resveratrol not only considerably halted the aberrant lymphotoxin (LT) production, but could also inhibit TNF $\alpha$ synthesis by MS B cells, even in subjects characterized by the highest levels of B cell TNF $\alpha$ production. Conversely, no effect on IL-10 levels was observed. Hence, resveratrol represents a promising treatment for the reduction of inflammation in the central nervous system (CNS) as well as in the periphery and in the target organ of patients presenting relapsing and progressive forms of the illness. These data are in accordance with previous observations reporting the protective effect of resveratrol against experimental autoimmune 
encephalomyelitis (EAE) by activating multiple SIRT1 targets $[128,129]$. Contrasting results regarding the neuroprotective effect of resveratrol on EAE models were reported by Sato et al. [130]. In more detail, significant exacerbation of autoimmune and viral models of MS, without exerting any neuroprotective activity in the CNS in both models following resveratrol treatment, was observed [130]. It is also plausible that the contrasting effects reported for resveratrol on cytokine production in EAE may depend on the stage and course of disease, dose administered or the use of different antigens used to sensitize the animals in different mouse strains [130].

\section{Conclusions}

Due to its multiple beneficial properties, including not only cardio and neuroprotective properties but also antioxidant, anti-inflammatory and anti-tumoral effects, the attention on the use of this compound in different pathological conditions is increased. Efforts should be made to evaluate further the compound during clinical trials and to translate the positive results obtained from in vitro and in vivo experiments into the development of a therapeutic agent to be used also for prevention of the onset of different diseases.

Author Contributions: Writing-original draft and figure preparation: E.G.; writing-review and editing, supervision, and funding acquisition: A.F. All authors have read and agreed to the published version of the manuscript.

Funding: This research received no external funding.

Conflicts of Interest: The authors declare no conflict of interest.

\section{References}

1. Pozzesi, N.; Pierangeli, S.; Vacca, C.; Vacca, C.; Falchi, L.; Pettorossi, V.; Martelli, M.P.; Thuy, T.T.; Ninh, P.T.; Liberati, A.M.; et al. Maesopsin 4-O-betad-glucoside, a natural compound isolated from the leaves of Artocarpus tonkinensis, inhibits proliferation and up-regulates HMOX1, SRXN1 and BCAS3 in acute myeloid leukemia. J. Chemother. 2011, 23, 150-157. [CrossRef] [PubMed]

2. Adorisio, S.; Fierabracci, A.; Gigliarelli, G.; Muscari, I.; Cannarile, L.; Liberati, A.M.; Marcotullio, M.C.; Riccardi, C.; Curini, M.; Robles Zepeda, R.E.; et al. The Hexane Fraction of Bursera microphylla A Gray Induces p21-Mediated Antiproliferative and Proapoptotic Effects in Human Cancer-Derived Cell Lines. Integr. Cancer Ther. 2017, 16, 426-435. [CrossRef] [PubMed]

3. Cragg, G.M.; Newman, D.J. Natural products: A continuing source of novel drug leads. Biochim. Biophys. Acta 2013, 1830, 3670-3695. [CrossRef] [PubMed]

4. Alonso-Castro, A.J. Use of medicinal fauna in Mexican traditional medicine. J. Ethnopharmacol. 2014, 152, 53-70. [CrossRef]

5. DeWeerdt, S. The edible skincare diet. Nature 2018, 563, S94-S95. [CrossRef]

6. Rudolf, E.; Andelová, H.; Cervinka, M. Polyphenolic compounds in chemoprevention of colon cancer-targets and signaling pathways. Anticancer Agents Med. Chem. 2007, 7, 559-575. [CrossRef]

7. Jeandet, P.; Bessis, R.; Maume, B.F.; Meunier, P.; Peyron, D.; Trollat, P. Effect of enological practices on the resveratrol isomer content of wine. J. Agric. Food Chem. 1995, 43, 316-319. [CrossRef]

8. Sales, J.M.; Resurreccion, A.V.A. Resveratrol in peanuts. Crit. Rev. Food Sci. Nutr. 2014, 54, 734-770. [CrossRef]

9. Lyons, M.M.; Yu, C.; Toma, R.B.; Cho, S.Y.; Reiboldt, W.; Lee, J.; van Breemen, R.B. Resveratrol in raw and baked blueberries and bilberries. J. Agric. Food Chem. 2003, 51, 5867-5870. [CrossRef]

10. Raal, A.; Pokk, P.; Arend, A.; Aunapuu, M.; Jõgi, J.; Okva, K.; Püssa, T. Trans-resveratrol alone and hydroxystilbenes of rhubarb (Rheum rhaponticum L.) root reduce liver damage induced by chronic ethanol administration: A comparative study in mice. Phytother. Res. 2009, 23, 525-532. [CrossRef]

11. Chaudhary, Z.; Subramaniam, S.; Khan, G.M.; Abeer, M.M.; Qu, Z.; Janjua, T.; Kumeria, T.; Batra, J.; Popat, A. Encapsulation and Controlled Release of Resveratrol Within Functionalized Mesoporous Silica Nanoparticles for Prostate Cancer Therapy. Front. Bioeng. Biotechnol. 2019, 7, 225. [CrossRef] [PubMed] 
12. Sajadimajd, S.; Bahramsoltani, R.; Iranpanah, A.; Kumar Patra, J.; Das, G.; Gouda, S.; Rahimi, R.; Rezaeiamiri, E.; Cao, H.; Giampieri, F.; et al. Advances on Natural Polyphenols as Anticancer Agents for Skin Cancer. Pharmacol. Res. 2019, 151, 104584. [CrossRef] [PubMed]

13. Ma, D.S.L.; Tan, L.T.; Chan, K.G.; Yap, W.H.; Pusparajah, P.; Chuah, L.H.; Ming, L.C.; Khan, T.M.; Lee, L.H.; Goh, B.H. Resveratrol-Potential Antibacterial Agent against Foodborne Pathogens. Front. Pharmacol. 2018, 9 , 102. [CrossRef] [PubMed]

14. Mattio, L.M.; Dallavalle, S.; Musso, L.; Filardi, R.; Franzetti, L.; Pellegrino, L.; D’Incecco, P.; Mora, D.; Pinto, A.; Arioli, S. Antimicrobial activity of resveratrol-derived monomers and dimers against foodborne pathogens. Sci. Rep. 2019, 9, 19525. [CrossRef]

15. Xu, G.; Zhao, X.; Fu, J.; Wang, X. Resveratrol increase myocardial Nrf2 expression in type 2 diabetic rats and alleviate myocardial ischemia/reperfusion injury (MIRI). Ann. Palliat. Med. 2019, 8, 565-575. [CrossRef]

16. Cieślik-Boczula, K. Influence of resveratrol on interactions between negatively charged DPPC/DPPG membranes and positively charged poly-l-lysine. Chem. Phys. Lipids 2018, 214, 24-34. [CrossRef]

17. Malaguarnera, L. Influence of Resveratrol on the Immune Response. Nutrients 2019, 11, 946. [CrossRef]

18. Chen, M.; Fu, Q.; Song, X.; Muhammad, A.; Jia, R.; Zou, Y.; Yin, L.; Li, L.; He, C.; Ye, G.; et al. Preparation of resveratrol dry suspension and its immunomodulatory and anti-inflammatory activity in mice. Pharm. Biol. 2020, 58, 8-15. [CrossRef]

19. Van Duursen, M.B.M. Modulation of estrogen synthesis and metabolism by phytoestrogens in vitro and the implications for women's health. Toxicol. Res. 2017, 6, 772-794. [CrossRef]

20. Jeandet, P.; Delaunois, B.; Conreux, A.; Donnez, D.; Nuzzo, V.; Cordelier, S.; Clément, C.; Courot, E. Biosynthesis, metabolism, molecular engineering, and biological functions of stilbene phytoalexins in plants. Biofactors 2010, 36, 331-341. [CrossRef]

21. Chang, X.; Heene, E.; Qiao, F.; Nick, P. The Phytoalexin Resveratrol Regulates the Initiation of Hypersensitive Cell Death in Vitis Cell. PLoS ONE 2011, 6, e26405. [CrossRef]

22. Siemann, E.H.; Creasy, L.L. Concentration of the Phytoalexin Resveratrol in Wine. Am. J. Enol. Vitic. 1992, 43, $49-52$.

23. Catalgol, B.; Batirel, S.; Taga, Y.; Ozer, N.K. Resveratrol: French paradox revisited. Front. Pharmacol. 2012, 3, 141. [CrossRef]

24. Jang, M.; Cai, L.; Udeani, G.O.; Slowing, K.V.; Thomas, C.F.; Beecher, C.W.; Fong, H.H.; Farnsworth, N.R.; Kinghorn, A.D.; Mehta, R.G.; et al. Cancer chemopreventive activity of resveratrol, a natural product derived from grapes. Science 1997, 275, 218-220. [CrossRef]

25. Ahmad, A.; Syed, F.A.; Singh, S.; Hadi, S.M. Prooxidant activity of resveratrol in the presence of copper ions: Mutagenicity in plasmid DNA. Toxicol. Lett. 2005, 159,1-12. [CrossRef]

26. Rossi, M.; Caruso, F.; Antonioletti, R.; Viglianti, A.; Traversi, G.; Leone, S.; Basso, E.; Cozzi, R. Scavenging of hydroxyl radical by resveratrol and related natural stilbenes after hydrogen peroxide attack on DNA. Chem. Biol. Interact. 2013, 206, 175-185. [CrossRef]

27. Dröge, W. Free radicals in the physiological control of cell function. Physiol. Rev. 2002, 82, 47-95. [CrossRef]

28. Chatgilialoglu, C.; Ferreri, C.; Geacintov, N.E.; Krokidis, M.G.; Liu, Y.; Masi, A.; Shafirovich, V.; Terzidis, M.A.; Tsegay, P.S. 5',8-Cyclopurine Lesions in DNA Damage: Chemical, Analytical, Biological, and Diagnostic Significance. Cells 2019, 8, 513. [CrossRef]

29. Gonzalez-Hunt, C.P.; Wadhwa, M.; Sanders, L.H. DNA damage by oxidative stress: Measurement strategies for two genomes. Curr. Opin. Toxicol. 2018, 7, 87-94. [CrossRef]

30. Li, X.; Qiu, S.; Shi, J.; Wang, S.; Wang, M.; Xu, Y.; Nie, Z.; Liu, C.; Liu, C. A new function of copper zinc superoxide dismutase: As a regulatory DNA-binding protein in gene expression in response to intracellular hydrogen peroxide. Nucleic Acids Res. 2019, 47, 5074-5085. [CrossRef]

31. Aggarwal, B.B.; Bhardwaj, A.; Aggarwal, R.S.; Seeram, N.P.; Shishodia, S.; Takada, Y. Role of resveratrol in prevention and therapy of cancer: Preclinical and clinical studies. Anticancer Res. 2004, 24, 2783-2840.

32. Shankar, S.; Singh, G.; Srivastava, R.K. Chemoprevention by resveratrol: Molecular mechanisms and therapeutic potential. Front. Biosci. 2007, 12, 4839-4854. [CrossRef]

33. Wang, Z.; Dabrosin, C.; Yin, X.; Fuster, M.M.; Arreola, A.; Rathmell, W.K.; Generali, D.; Nagaraju, G.P.; El-Rayes, B.; Ribatti, D.; et al. Broad targeting of angiogenesis for cancer prevention and therapy. Semin. Cancer Biol. 2015, 35, S224-S243. [CrossRef] [PubMed] 
34. Ko, J.H.; Sethi, G.; Um, J.Y.; Shanmugam, M.K.; Arfuso, F.; Kumar, A.P.; Bishayee, A.; Ahn, K.S. The Role of Resveratrol in Cancer Therapy. Int. J. Mol. Sci. 2017, 18, 2589. [CrossRef] [PubMed]

35. Švajger, U.; Jeras, M. Anti-inflammatory effects of Resveratrol and its potential use in therapy of immune-mediated diseases. Int. Rev. Immunol. 2012, 31, 202-222. [CrossRef] [PubMed]

36. Sharma, S.; Chopra, K.; Kulkarni, S.K.; Agrewala, J.N. Resveratrol and curcumin suppress immune response through CD28/CTLA-4 and CD80 co-stimulatory pathway. Clin. Exp. Immunol. 2007, 147, 155-163. [CrossRef] [PubMed]

37. Yang, Y.; Paik, J.H.; Cho, D.; Cho, J.A.; Kim, C.W. Resveratrol induces the suppression of tumor-derived CD4+CD25+ regulatory T cells. Int. Immunopharmacol. 2008, 8, 542-547. [CrossRef]

38. Jhou, J.P.; Chen, S.J.; Huang, H.Y.; Lin, W.W.; Huang, D.Y.; Tzeng, S.J. Upregulation of Fc $\gamma$ RIIB by Resveratrol via NF-kB activation reduces B-cell numbers and ameliorates lupus. Exp. Mol. Med. 2017, 49, e381. [CrossRef]

39. Juan, M.E.; Buenafuente, J.; Casals, I.; Planas, J.M. Plasmatic levels of trans-resveratrol in rats. Food Res. Int. 2002, 35, 195-199. [CrossRef]

40. Andlauer, W.; Kolb, J.; Siebert, K.; Fürst, P. Assessment of resveratrol bioavailability in the perfused small intestine of the rat. Drugs Exp. Clin. Res. 2000, 26, 47-55.

41. Sabolovic, N.; Humbert, A.C.; Radominska-Pandya, A.; Magdalou, J. Resveratrol is efficiently glucuronidated by UDP-glucuronosyltransferases in the human gastrointestinal tract and in Caco-2 cells. Biopharm. Drug Dispos. 2006, 27, 181-189. [CrossRef] [PubMed]

42. Brill, S.S.; Furimsky, A.M.; Ho, M.N.; Furniss, M.J.; Li, Y.; Green, A.G.; Bradford, W.W.; Green, C.E.; Kapetanovic, I.M.; Iyer, L.V. Glucuronidation of trans-resveratrol by human liver and intestinal microsomes and UGT isoforms. J. Pharm. Pharmacol. 2006, 58, 469-479. [CrossRef] [PubMed]

43. Wen, X.; Walle, T. Methylated flavonoids have greatly improved intestinal absorption and metabolic stability. Drug Metab. Dispos. 2006, 34, 1786-1792. [CrossRef] [PubMed]

44. Traversi, G.; Staid, D.S.; Fiore, M.; Percario, Z.; Trisciuoglio, D.; Antonioletti, R.; Morea, V.; Degrassi, F.; Cozzi, R. A novel resveratrol derivative induces mitotic arrest, centrosome fragmentation and cancer cell death by inhibiting $\gamma$-tubulin. Cell Div. 2019, 14, 3. [CrossRef]

45. Jeandet, P.; Sobarzo-Sánchez, E.; Clément, C.; Nabavi, S.F.; Habtemariam, S.; Nabavi, S.M.; Cordelier, S. Engineering stilbene metabolic pathways in microbial cells. Biotechnol. Adv. 2018, 36, 2264-2283. [CrossRef]

46. Jeandet, P.; Sobarzo-Sánchez, E.; Sanches Silva, A.; Clément, C.; Fazel Nabavi, S.; Battino, M.; Rasekhian, M.; Belwal, T.; Habtemariam, S.; Koffas, M.; et al. Whole-cell biocatalytic, enzymatic and green chemistry methods for the production of resveratrol and its derivatives. Biotechnol. Adv. 2019. [CrossRef]

47. Son, Y.; Chung, H.T.; Pae, H.O. Differential effects of resveratrol and its natural analogs, piceatannol and 3,5,4'-trans-trimethoxystilbene, on anti-inflammatory heme oxigenase-1 expression in RAW264.7 macrophages. Biofactors 2014, 40, 138-145. [CrossRef]

48. Fulda, S. Resveratrol and derivatives for the prevention and treatment of cancer. Drug Discov. Today 2010, 15, 757-765. [CrossRef]

49. Riche, D.M.; McEwen, C.L.; Riche, K.D.; Sherman, J.J.; Wofford, M.R.; Deschamp, D.; Griswold, M. Analysis of safety from a human clinical trial with pterostilbene. J. Toxicol. 2013, 2013, 463595. [CrossRef]

50. Chatterjee, K.; Mukherjee, S.; Vanmanen, J.; Banerjee, P.; Fata, J.E. Dietary Polyphenols, Resveratrol and Pterostilbene Exhibit Antitumor Activity on an HPV E6-Positive Cervical Cancer Model: An in vitro and in vivo Analysis. Front. Oncol. 2019, 9, 352. [CrossRef]

51. Cancer. Available online: www.who.int/cancer/en/ (accessed on 15 August 2019).

52. Yeung, F.; Hoberg, J.E.; Ramsey, C.S.; Keller, M.D.; Jones, D.R.; Frye, R.A.; Mayo, M.W. Modulation of NF-kB-dependent transcription and cell survival by the SIRT1 deacetylase. EMBO J. 2004, 23, 2369-2380. [CrossRef] [PubMed]

53. Kozuki, Y.; Miura, Y.; Yagasaki, K. Resveratrol suppresses hepatoma cell invasion independently of its anti-proliferative action. Cancer Lett. 2001, 167, 151-156. [CrossRef]

54. Gwak, H.; Kim, S.; Dhanasekaran, D.N.; Song, Y.S. Resveratrol triggers ER stress-mediated apoptosis by disrupting N-linked glycosylation of proteins in ovarian cancer cells. Cancer Lett. 2016, 371, 347-353. [CrossRef] [PubMed]

55. Zhong, L.X.; Wu, M.L.; Li, H.; Liu, J.; Lin, L.Z. Efficacy and safety of intraperitoneally administered resveratrol against rat orthotopic ovarian cancers. Cancer Manag. Res. 2019, 11, 6113-6124. [CrossRef] [PubMed] 
56. Liu, Y.; Tong, L.; Luo, Y.; Li, X.; Chen, G.; Wang, Y. Resveratrol inhibits the proliferation and induces the apoptosis in ovarian cancer cells via inhibiting glycolysis and targeting AMPK/mTOR signaling pathway. J. Cell. Biochem. 2018, 119, 6162-6172. [CrossRef]

57. Zhang, Y.; Yang, S.; Yang, Y.; Liu, T. Resveratrol induces immunogenic cell death of human and murine ovarian carcinoma cells. Infect. Agents Cancer 2019, 14, 27. [CrossRef]

58. Reagan-Shaw, S.; Mukhtar, H.; Ahmad, N. Resveratrol imparts photoprotection of normal cells and enhances the efficacy of radiation therapy in cancer cells. Photochem. Photobiol. 2008, 84, 415-421. [CrossRef]

59. Fang, Y.; Bradley, M.; Cook, K.; Herrick, E.; Nicholl, M. A potential role for resveratrol as a radiation sensitizer for melanoma treatment. J. Surg. Res. 2013, 183, 645-653. [CrossRef]

60. Lee, J.H.; Wendorff, T.J.; Berger, J.M. Resveratrol: A novel type of topoisomerase II inhibitor. J. Biol. Chem. 2017, 292, 21011-21022. [CrossRef]

61. Nitiss, J.L. DNA topoisomerase II and its growing repertoire of biological functions. Nat. Rev. Cancer 2009, 9, 327-337. [CrossRef]

62. Wang, J.C. DNA topoisomerases. Annu. Rev. Biochem. 1985, 54, 665-697. [CrossRef] [PubMed]

63. Baechler, S.A.; Schroeter, A.; Dicker, M.; Steinberg, P.; Marko, D. Topoisomerase II-targeting properties of a grapevine-shoot extract and resveratrol oligomers. J. Agric. Food Chem. 2014, 62, 780-788. [CrossRef] [PubMed]

64. Demoulin, B.; Hermant, M.; Castrogiovanni, C.; Staudt, C.; Dumont, P. Resveratrol induces DNA damage in colon cancer cells by poisoning topoisomerase II and activates the ATM kinase to trigger p53-dependent apoptosis. Toxicol. In Vitro 2015, 29, 1156-1165. [CrossRef] [PubMed]

65. Lin, C.C.; Chin, Y.T.; Shih, Y.J.; Chen, Y.R.; Chung, Y.Y.; Lin, C.Y.; Hsiung, C.N.; Whang-Peng, J.; Lee, S.Y.; Lin, H.Y.; et al. Resveratrol antagonizes thyroid hormone-induced expression of checkpoint and proliferative genes in oral cancer cells. J. Dent. Sci. 2019, 14, 255-262. [CrossRef]

66. Mohan, A.; Narayanan, S.; Sethuraman, S.; Krishnan, U.M. Novel resveratrol and 5-fluorouracil coencapsulated in PEGylated nanoliposomes improve chemotherapeutic efficacy of combination against head and neck squamous cell carcinoma. BioMed Res. Int. 2014, 2014, 424239. [CrossRef]

67. Gatouillat, G.; Balasse, E.; Joseph-Pietras, D.; Morjani, H.; Madoulet, C. Resveratrol induces cell-cycle disruption and apoptosis in chemoresistant B16 melanoma. J. Cell. Biochem. 2010, 110, 893-902. [CrossRef]

68. Yuan, Y.; Xue, X.; Guo, R.B.; Sun, X.L.; Hu, G. Resveratrol enhances the antitumor effects of temozolomide in glioblastoma via ROS-dependent AMPK-TSC-mTOR signaling pathway. CNS Neurosci. Ther. 2012, 18, 536-546. [CrossRef]

69. Zeng, Y.; Li, F.D.; Shi, C.W.; Du, J.L.; Xue, Y.J.; Liu, X.Y.; Cao, X.; Wei, N. Mechanism and therapeutic prospect of resveratrol combined with TRAIL in the treatment of renal cell carcinoma. Cancer Gene Ther. 2019. [CrossRef]

70. Alosi, J.A.; McDonald, D.E.; Schneider, J.S.; Privette, A.R.; McFadden, D.W. Pterostilbene Inhibits Breast Cancer In Vitro Through Mitochondrial Depolarization and Induction of Caspase-Dependent Apoptosis. J. Surg. Res. 2010, 161, 195-201. [CrossRef]

71. Kala, R.; Shah, H.N.; Martin, S.L.; Tollefsbol, T.O. Epigenetic-based combinatorial resveratrol and pterostilbene alters DNA damage response by affecting SIRT1 and DNMT enzyme expression, including SIRT1-dependent $\gamma-\mathrm{H} 2 \mathrm{AX}$ and telomerase regulation in triple-negative breast cancer. BMC Cancer 2015, 15, 672. [CrossRef]

72. Kala, R.; Tollefsbol, T.O. A Novel Combinatorial Epigenetic Therapy Using Resveratrol and Pterostilbene for Restoring Estrogen Receptor- $\alpha(\mathrm{ER} \alpha)$ Expression in ER $\alpha$-Negative Breast Cancer Cells. PLoS ONE 2016, 11, e0155057. [CrossRef] [PubMed]

73. Fan, C.; Kong, F.; Shetti, D.; Zhang, B.; Yang, Y.; Wei, K. Resveratrol loaded oxidized mesoporous carbon nanoparticles: A promising tool to treat triple negative breast cancer. Biochem. Biophys. Res. Commun. 2019, 519, 378-384. [CrossRef] [PubMed]

74. Thipe, V.C.; Panjtan Amiri, K.; Bloebaum, P.; Raphael Karikachery, A.; Khoobchandani, M.; Katti, K.K.; Jurisson, S.S.; Katti, K.V. Development of resveratrol-conjugated gold nanoparticles: Interrelationship of increased resveratrol corona on anti-tumor efficacy against breast, pancreatic and prostate cancers. Int. J. Nanomed. 2019, 14, 4413-4428. [CrossRef] [PubMed]

75. Androutsopoulos, V.P.; Fragiadaki, I.; Spandidos, D.A.; Tosca, A. The resveratrol analogue, 3,4,5,4'-trans-tetramethoxystilbene, inhibits the growth of A375 melanoma cells through multiple anticancer modes of action. Int. J. Oncol. 2016, 49, 1305-1314. [CrossRef] 
76. Fan, X.X.; Yao, X.J.; Xu, S.W.; Wong, V.K.; He, J.X.; Ding, J.; Xue, W.W.; Mujtaba, T.; Michelangeli, F.; Huang, M.; et al. (Z)3,4,5,4'-trans-tetramethoxystilbene, a new analogue of resveratrol, inhibits gefitinb-resistant non-small cell lung cancer via selectively elevating intracellular calcium level. Sci. Rep. 2015, 5, 16348. [CrossRef]

77. Lu, M.; Liu, B.; Xiong, H.; Wu, F.; Hu, C.; Liu, P. Trans-3,5,4'-trimethoxystilbene reduced gefitinib resistance in NSCLCs via suppressing MAPK/Akt/Bcl-2 pathway by upregulation of miR-345 and miR-498. J. Cell. Mol. Med. 2019, 23, 2431-2441. [CrossRef]

78. Stivala, L.A.; Savio, M.; Carafoli, F.; Perucca, P.; Bianchi, L.; Maga, G.; Forti, L.; Pagnoni, U.M.; Albini, A.; Prosperi, E.; et al. Specific structural determinants are responsible for the antioxidant activity and the cell cycle effects of resveratrol. J. Biol. Chem. 2001, 276, 22586-22594. [CrossRef]

79. Alex, D.; Leong, E.C.; Zhang, Z.J.; Yan, G.T.; Cheng, S.H.; Leong, C.W.; Li, Z.H.; Lam, K.H.; Chan, S.W.; Lee, S.M. Resveratrol derivative, trans-3,5,4'-trimethoxystilbene, exerts antiangiogenic and vascular-disrupting effects in zebrafish through the downregulation of VEGFR2 and cell-cycle modulation. J. Cell. Biochem. 2010, 109, 339-346.

80. Belleri, M.; Ribatti, D.; Nicoli, S.; Cotelli, F.; Forti, L.; Vannini, V.; Stivala, L.A.; Presta, M. Antiangiogenic and vascular-targeting activity of the microtubule-destabilizing trans-resveratrol derivative 3,5,4'-trimethoxystilbene. Mol. Pharmacol. 2005, 67, 1451-1459. [CrossRef]

81. Weng, C.J.; Wu, C.F.; Huang, H.W.; Wu, C.H.; Ho, C.T.; Yen, G.C. Evaluation of Anti-Invasion Effect of Resveratrol and Related Methoxy Analogues on Human Hepatocarcinoma Cells. J. Agric. Food Chem. 2010, 58, 2886-2894. [CrossRef]

82. Cottart, C.H.; Nivet-Antoine, V.; Beaudeux, J.L. Review of recent data on the metabolism, biological effects, and toxicity of resveratrol in humans. Mol. Nutr. Food Res. 2014, 58, 7-21. [CrossRef] [PubMed]

83. Ma, Z.; Molavi, O.; Haddadi, A.; Lai, R.; Gossage, R.; Lavasanifar, A. Resveratrol analog trans 3,4,5,4'-tetramethoxystilbene (DMU-212) mediates anti-tumor effects via mechanism different from that of resveratrol. Cancer Chemother. Pharmacol. 2008, 63, 27-35. [CrossRef] [PubMed]

84. Androutsopoulos, V.P.; Fragiadaki, I.; Tosca, A. Activation of ERK1/2 is required for the antimitotic activity of the resveratrol analogue 3,4,5, $4^{\prime}$-tetramethoxystilbene (DMU-212) in human melanoma cells. Exp. Dermatol. 2015, 24, 632-634. [CrossRef] [PubMed]

85. Bernhard, D.; Tinhofer, I.; Tonko, M.; Hübl, H.; Ausserlechner, M.J.; Greil, R.; Kofler, R.; Csordas, A. Resveratrol causes arrest in the S-phase prior to Fas-independent apoptosis in CEM-C7H2 acute leukemia cells. Cell Death Differ. 2000, 7, 834-842. [CrossRef]

86. Luzi, C.; Brisdelli, F.; Cinque, B.; Cifone, G.; Bozzi, A. Differential sensitivity to resveratrol-induced apoptosis of human chronic myeloid (K562) and acute lymphoblastic (HSB-2) leukemia cells. Biochem. Pharmacol. 2004, 68, 2019-2030. [CrossRef]

87. Li, T.; Fan, G.X.; Wang, W.; Li, T.; Yuan, Y.K. Resveratrol induces apoptosis, influences IL-6 and exerts immunomodulatory effect on mouse lymphocytic leukemia both in vitro and in vivo. Int. Immunopharmacol. 2007, 7, 1221-1231. [CrossRef]

88. Clément, M.V.; Hirpara, J.L.; Chawdhury, S.H.; Pervaiz, S. Chemopreventive agent resveratrol, a natural product derived from grapes, triggers CD95 signaling-dependent apoptosis in human tumor cells. Blood 1998, 92, 996-1002. [CrossRef]

89. Sun, X.M.; MacFarlane, M.; Zhuang, J.; Wolf, B.B.; Green, D.R.; Cohen, G.M. Distinct caspase cascades are initiated in receptor-mediated and chemical-induced apoptosis. J. Biol. Chem. 1999, 274, 5053-5060. [CrossRef]

90. Roman, V.; Billard, C.; Kern, C.; Ferry-Dumazet, H.; Izard, J.C.; Mohammad, R.; Mossalayi, D.M.; Kolb, J.P. Analysis of resveratro1-induced apoptosis in human B-cell chronic leukemia. Br. J. Haematol. 2002, 117, 842-851. [CrossRef]

91. Tessitore, L.; Davit, A.; Sarotto, I.; Caderni, G. Resveratrol depresses the growth of colorectal aberrant crypt foci by affecting bax and p21 (CIP) expression. Carcinogenesis 2000, 21, 1619-1622. [CrossRef]

92. Li, G.; He, S.; Chang, L.; Lu, H.; Zhang, H.; Zhang, H.; Chiu, J. GADD45 $\alpha$ and annexin A1 are involved in the apoptosis of HL-60 induced by resveratrol. Phytomedicine 2011, 18, 704-709. [CrossRef]

93. Su, J.L.; Lin, M.T.; Hong, C.C.; Chang, C.C.; Shiah, S.G.; Wu, C.W.; Chen, S.T.; Chau, Y.P.; Kuo, M.L. Resveratrol induces FasL-related apoptosis through Cdc42 activation of ASK1/JNK-dependent signaling pathway in human leukemia HL-60 cells. Carcinogenesis 2005, 26, 1-10. [CrossRef] 
94. Cakir, Z.; Saydam, G.; Sahin, F.; Baran, Y. The roles of bioactive sphingolipids in resveratrol-induced apoptosis in HL60: Acute myeloid leukemia cells. J. Cancer Res. Clin. Oncol. 2011, 137, 279-286. [CrossRef] [PubMed]

95. Estrov, Z.; Shishodia, S.; Faderl, S.; Harris, D.; Van, Q.; Kantarjian, H.M.; Talpaz, M.; Aggarwal, B.B. Resveratrol blocks interleukin-1beta-induced activation of the nuclear transcription factor NF-kappaB, inhibits proliferation, causes S-phase arrest, and induces apoptosis of acute myeloid leukemia cells. Blood 2003, 102, 987-995. [CrossRef]

96. Yan, H.W.; Hu, W.X.; Zhang, J.Y.; Wang, Y.; Xia, K.; Peng, M.Y.; Liu, J. Resveratrol induces human K562 cell apoptosis, erythroid differentiation, and autophagy. Tumor Biol. 2014, 35, 5381-5388. [CrossRef]

97. Wang, T.T.; Hudson, T.S.; Wang, T.C.; Remsberg, C.M.; Davies, N.M.; Takahashi, Y.; Kim, Y.S.; Seifried, H.; Vinyard, B.T.; Perkins, S.N.; et al. Differential effects of resveratrol on androgen-responsive LNCaP human prostate cancer cells in vitro and in vivo. Carcinogenesis 2008, 29, 2001-2010. [CrossRef]

98. Castillo-Pichardo, L.; Cubano, L.A.; Dharmawardhane, S. Dietary grape polyphenol resveratrol increases mammary tumor growth and metastasis in immunocompromised mice. BMC Complement Altern. Med. 2013, 13, 6. [CrossRef]

99. Andreani, C.; Bartolacci, C.; Wijnant, K.; Crinelli, R.; Bianchi, M.; Magnani, M.; Hysi, A.; Iezzi, M.; Amici, A.; Marchini, C. Resveratrol fuels HER2 and ER $\alpha$-positive breast cancer behaving as proteasome inhibitor. Aging (Albany NY) 2017, 9, 508-523. [CrossRef]

100. Shaw, A.C.; Goldstein, D.R.; Montgomery, R.R. Age-dependent dysregulation of innate immunity. Nat. Rev. Immunol. 2013, 13, 875-887. [CrossRef]

101. Khan, H.; Sureda, A.; Belwal, T.; Çetinkaya, S.; Süntar, İ.; Tejada, S.; Devkota, H.P.; Ullah, H.; Aschner, M. Polyphenols in the treatment of autoimmune diseases. Autoimmun. Rev. 2019, 18, 647-657. [CrossRef]

102. McFarlane, I.G. Pathogenesis of autoimmune hepatitis. Biomed. Pharmacother. 1999, 53, 255-263. [CrossRef]

103. Ichiki, Y.; Aoki, C.A.; Bowlus, C.L.; Shimoda, S.; Ishibashi, H.; Gershwin, M.E. T cell immunity in autoimmune hepatitis. Autoimmun. Rev. 2005, 4, 315-321. [CrossRef]

104. Zhou, Y.; Chen, K.; He, L.; Xia, Y.; Dai, W.; Wang, F.; Li, J.; Li, S.; Liu, T.; Zheng, Y.; et al. The Protective Effect of Resveratrol on Concanavalin-A-Induced Acute Hepatic Injury in Mice. Gastroenterol. Res. Pract. 2015, 2015, 506390. [CrossRef]

105. Bertelli, A.A.; Giovannini, L.; Bernini, W.; Migliori, M.; Fregoni, M.; Bavaresco, L.; Bertelli, A. Antiplatelet activity of cis-resveratrol. Drugs Exp. Clin. Res. 1996, 22, 61-63.

106. Yun, J.M.; Chien, A.; Jialal, I.; Devaraj, S. Resveratrol up-regulates SIRT1 and inhibits cellular oxidative stress in the diabetic milieu: Mechanistic insights. J. Nutr. Biochem. 2012, 23, 699-705. [CrossRef]

107. Lee, S.M.; Yang, H.; Tartar, D.M.; Gao, B.; Luo, X.; Ye, S.Q.; Zaghouani, H.; Fang, D. Prevention and treatment of diabetes with resveratrol in a non-obese mouse model of type 1 diabetes. Diabetologia 2011, 54, 1136-1146. [CrossRef]

108. Kaur, G.; Padiya, R.; Adela, R.; Putcha, U.K.; Reddy, G.S.; Reddy, B.R.; Kumar, K.P.; Chakravarty, S.; Banerjee, S.K. Garlic and resveratrol attenuate diabetic complications, loss of $\beta$-cells, pancreatic and hepatic oxidative stress in streptozotocin-induced diabetic rats. Front. Pharmacol. 2016, 7, 1-15. [CrossRef]

109. Yonamine, C.Y.; Pinheiro-Machado, E.; Michalani, M.L.; Freitas, H.S.; Okamoto, M.M.; Corrêa-Giannella, M.L.; Machado, U.F. Resveratrol improves glycemic control in insulin-treated diabetic rats: Participation of the hepatic territory. Nutr. Metab. 2016, 13, 44. [CrossRef]

110. Fakhoury, M.; Negrulj, R.; Mooranian, A.; Al-Salami, H. Inflammatory bowel disease: Clinical aspects and treatments. J. Inflamm. Res. 2014, 7, 113-120. [CrossRef]

111. Larrosa, M.; Tomé-Carneiro, J.; Yáñez-Gascón, M.J.; Alcántara, D.; Selma, M.V.; Beltrán, D.; García-Conesa, M.T.; Urbán, C.; Lucas, R.; Tomás-Barberán, F.; et al. Preventive oral treatment with resveratrol pro-prodrugs drastically reduce colon inflammation in rodents. J. Med. Chem. 2010, 53, 7365-7376. [CrossRef]

112. Sánchez-Fidalgo, S.; Cárdeno, A.; Villegas, I.; Talero, E.; de la Lastra, C.A. Dietary supplementation of resveratrol attenuates chronic colonic inflammation in mice. Eur. J. Pharmacol. 2010, 633, 78-84. [CrossRef]

113. Rahal, K.; Schmiedlin-Ren, P.; Adler, J.; Dhanani, M.; Sultani, V.; Rittershaus, A.C.; Reingold, L.; Zhu, J.; Mckenna, B.J.; Christman, G.M.; et al. Resveratrol has antiinflammatory and antifibrotic effects in the peptidoglycan-polysaccharide rat model of Crohn's disease. Inflamm. Bowel Dis. 2012, 18, 613-623. [CrossRef] 
114. Lozano-Pérez, A.A.; Rodriguez-Nogales, A.; Ortiz-cullera, V.; Algieri, F.; Garrido-Mesa, J.; Zorrilla, P.; Rodriguez-Cabezas, M.E.; Garrido-Mesa, N.; Utrilla, M.P.; De Matteis, L.; et al. Silk fibroin nanoparticles constitute a vector for controlled release of resveratrol in an experimental model of inflammatory bowel disease in rats. Int. J. Nanomed. 2014, 9, 4507-4520.

115. Yildiz, G.; Yildiz, Y.; Ulutas, P.A.; Yaylali, A.; Ural, M. Resveratrol Pretreatment Ameliorates TNBS Colitis in Rats. Recent Pat. Endoc. Metab. Immune Drug Discov. 2015, 9, 134-140. [CrossRef] [PubMed]

116. Gianchecchi, E.; Fierabracci, A. Recent Advances on Microbiota Involvement in the Pathogenesis of Autoimmunity. Int. J. Mol. Sci. 2019, 20, 283. [CrossRef] [PubMed]

117. Martín, A.R.; Villegas, I.; La Casa, C.; De La Lastra, C.A. Resveratrol, a polyphenol found in grapes, suppresses oxidative damage and stimulates apoptosis during early colonic inflammation in rats. Biochem. Pharmacol. 2004, 67, 1399-1410.

118. Samsamikor, M.; Daryani, E.; Asl, R.; Hekmatdoost, A. Anti-Inflammatory Effects of Resveratrol in Patients with Ulcerative Colitis: A Randomized, Double-Blind, Placebo-controlled Pilot Study. Arch. Med. Res. 2015, 46, 280-285. [CrossRef]

119. Coradini, K.; Friedrich, R.B.; Fonseca, F.N.; Vencato, M.S.; Andrade, D.F.; Oliveira, C.M.; Battistel, A.P.; Guterres, S.S.; da Rocha, M.I.; Pohlmann, A.R.; et al. A novel approach to arthritis treatment based on resveratrol and curcumin co-encapsulated in lipid-core nanocapsules: In vivo studies. Eur. J. Pharm. Sci. 2015, 78, 163-170. [CrossRef]

120. Riveiro-Naveira, R.R.; Valcárcel-Ares, M.N.; Almonte-Becerril, M.; Vaamonde-García, C.; Loureiro, J.; Hermida-Carballo, L.; López-Peláez, E.; Blanco, F.J.; López-Armada, M.J. Resveratrol lowers synovial hyperplasia, inflammatory markers and oxidative damage in an acute antigen-induced arthritis model. Rheumatology 2016, 55, 1889-1900. [CrossRef]

121. Wang, P.; Ren, D.; Chen, Y.; Jiang, M.; Wang, R.; Wang, Y.G. Effect of sodium alginate addition to resveratrol on acute gouty arthritis. Cell. Physiol. Biochem. 2015, 36, 201-207. [CrossRef]

122. Chen, H.; Zheng, S.; Wang, Y.; Zhu, H.; Liu, Q.; Xue, Y.; Qiu, J.; Zou, H.; Zhu, X. The effect of resveratrol on the recurrent attacks of gouty arthritis. Clin. Rheumatol. 2016, 35, 1189-1195. [CrossRef] [PubMed]

123. Wang, Z.L.; Luo, X.F.; Li, M.T.; Xu, D.; Zhou, S.; Chen, H.Z.; Gao, N.; Chen, Z.; Zhang, L.L.; Zeng, X.F. Resveratrol possesses protective effects in a pristane-induced lupus mouse model. PLoS ONE 2014, 9, e0114792. [CrossRef] [PubMed]

124. Feng, X.; Li, H.; Rumbin, A.A.; Wang, X.; La Cava, A.; Brechtelsbauer, K.; Castellani, L.W.; Witztum, J.L.; Lusis, A.J.; Tsao, B.P. ApoE ${ }^{-/-}$Fas $^{-/-}$C57BL/6 mice: A novel murine model simultaneously exhibits lupus nephritis, atherosclerosis, and osteopenia. J. Lipid Res. 2007, 48, 794-805. [CrossRef] [PubMed]

125. Voloshyna, I.; Hai, O.; Littlefield, M.J.; Carsons, S.; Reiss, A.B. Resveratrol mediates anti-atherogenic effects on cholesterol flux in human macrophages and endothelium via PPAR $\gamma$ and adenosine. Eur. J. Pharmacol. 2013, 698, 299-309. [CrossRef]

126. Voloshyna, I.; Teboul, I.; Littlefield, M.J.; Siegart, N.M.; Turi, G.K.; Fazzari, M.J.; Carsons, S.E.; DeLeon, J.; Reiss, A.B. Resveratrol counters systemic lupus erythematosus-associated atherogenicity by normalizing cholesterol efflux. Exp. Biol. Med. 2016, 241, 1611-1619. [CrossRef]

127. Miyazaki, Y.; Li, R.; Rezk, A.; Misirliyan, H.; Moore, C.; Farooqi, N.; Solis, M.; Goiry, L.G.; de Faria Junior, O.; Dang, V.D.; et al. A novel microRNA-132-sirtuin-1 axis underlies aberrant B-cell cytokine regulation in patients with relapsing-remitting multiple sclerosis. PLoS ONE 2014, 9, e105421. [CrossRef]

128. Shindler, K.S.; Ventura, E.; Dutt, M.; Elliott, P.; Fitzgerald, D.C.; Rostami, A. Oral resveratrol reduces neuronal damage in a model of multiple sclerosis. J. Neuroophthalmol. 2010, 30, 328-339. [CrossRef]

129. Nimmagadda, V.K.; Bever, C.T.; Vattikunta, N.R.; Talat, S.; Ahmad, V.; Nagalla, N.K.; Trisler, D.; Judge, S.I.; Royal, W.; Chandrasekaran, K.; et al. Overexpression of SIRT1 protein in neuron protects against experimental autoimmune encephalomyelitis through activation of multiple SIRT1 targets. J. Immunol. 2013, 190, 4595-4607. [CrossRef]

130. Sato, F.; Martinez, N.E.; Shahid, M.; Rose, J.W.; Carlson, N.G.; Tsunoda, I. Resveratrol exacerbates both autoimmune and viral models of multiple sclerosis. Am. J. Pathol. 2013, 183, 1390-1396. [CrossRef]

(C) 2020 by the authors. Licensee MDPI, Basel, Switzerland. This article is an open access article distributed under the terms and conditions of the Creative Commons Attribution (CC BY) license (http://creativecommons.org/licenses/by/4.0/). 